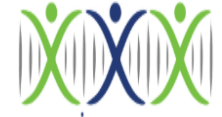

iRASD
Pakistan Journal of Humanities and Social Sciences

Volume 9, Number 3, 2021, Pages 505-514

Journal Homepage:

https://journals.internationalrasd.org/index.php/pjhss

\title{
Women Empowerment in Punjab: Dimensions, Determinants, and Implications for Access to Healthcare
}

\author{
Dilshad Ahmad' ${ }^{1}$, Salyha Zulfiqar Ali Shah², Furrukh Bashir ${ }^{3}$ \\ ${ }^{1}$ Department of Management Sciences, COMSATS University Islamabad, Vehari Campus Pakistan. \\ Email: dilshad@ciitvehari.edu.pk \\ 2 Assistant Professor, School of Economics, Bahauddin Zakariya University Multan, Pakistan. \\ Email: salyhazulfiqar@bzu.edu.pk \\ ${ }^{3}$ Assistant Professor, School of Economics, Bahauddin Zakariya University Multan, Pakistan. \\ Email: furrukh@bzu.edu.pk
}

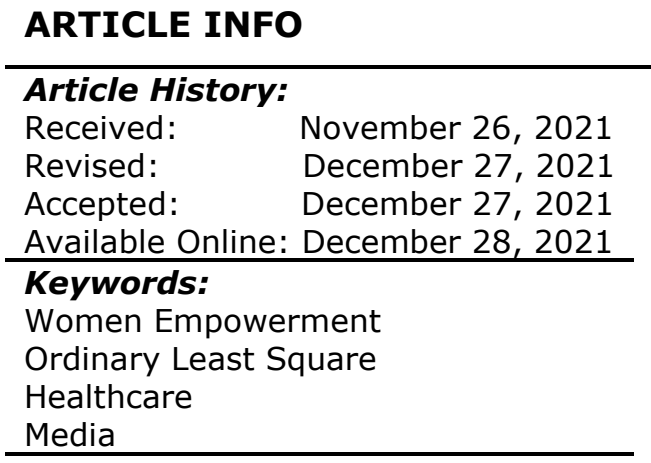

ABSTRACT

In developing countries like Pakistan, because of the complex cultural and socio-demographic milieu women empowerment always remained the contested issue. Overall major indicators of human development of women have been considered lower rather than men. In Pakistan, some considerable measures have focused on women's empowerment however, their status is still miserable specifically in rural areas. This study was aimed to find out, the extent of rural women empowerment and the effect of women empowerment regarding access to healthcare in the Vehari district of Southern Punjab, Pakistan. The study used data of 240 married women respondents and employed Cronbach's alpha and OLS approaches for various analyses of the study components. Scores of various components regarding women's empowerment were regressed over the scores of women's access to healthcare in the final analysis of the study. The finding of the study indicated that the power of decisionmaking (0.87), self-esteem (0.79), and mobility (0.89) has positive and significant effects on access to health care whereas control over the resource (0.73) estimates indicated positive while the insignificant impact on health access. Education access, adequate job opportunities, and media information approach considered more appropriate and feasible measures for adequate women empowerment and health care access. Emergency-based State-based policy measures need to be applied such as women schooling at doorstep, increasing females' priority-based job opportunities, and proper access to media for increasing awareness regarding their rights and significant role in society.

(c) 2021 The Authors, Published by iRASD. This is an Open Access Article under the Creative Common Attribution Non-Commercial 4.0

Corresponding Author's Email: salyhazulfiqar@bzu.edu.pk

\section{Introduction}

Social awareness in the global scenario highlighted some significant issues among them inadequate women empowerment and gender inequality are more alarming (Murtza, 2012; Zakar et al., 2017; Thandar et al., 2019; Peterman et al., 2021). Empowerment permits individuals to believe in their capabilities, boost their social as well as economic participation and reach their full potential (Kandpal et al., 2013; Yaya et al., 2019; Sohn et al., 2020). Empowerment is essential for both genders, however; it is close, associated with women because women's disempowerment is more prevalent (Malhotra, 2005; Sebayang et al., 2019; Peterman et al., 2021). According to the United Nations (2017), empowerment of women refers to their basic right of having strength so they can control their personal lives in their homes as well as outside their houses also. Empowerment allows women to own material and intellectual resources that make them self-governing and self-supportive (Jali et al., 2017; Sano et al., 2018; Cornish et al., 2021). Almost half of the world's population consists of women (Jali et al., 2017; Peterman et al., 2021). Unfortunately, in different regions of the 
world, women are relatively unable are attaining the rights due to male dominance ideology (Karim et al., 2017; Nieuwenhuijze and Leahy-Warren, 2019). Women have less accessibility of their rights and there is a secondary role available for women in society (Panigraphy and Bhuyan, 2006; Merrell and Blackstone, 2020). Factors responsible for the miserable condition of women are fewer job opportunities for women, a lesser decision-making power of women and women's decisions benefiting others, etc (Bradshaw \& Linneker, 2003; Chomchoei et al., 2019).

Around half of the population of Pakistan consists of women but unfortunately, they are treated roughly and are not playing a significant role in the development of the country (Patel, 2010; Yaya et al., 2019). Pakistan is such a country having wider gender bias and inequality against women in South Asia (UNICEF, 2017; Cornish et al., 2021). The constitution of Pakistan protects the rights of women while the scenario is different as these rights are usually violated and dishonored by various segments of society (Khan, 2017; Sohn et al., 2020). The deep-rooted gender inequality, socio-cultural norms and values influence the status of women in the society of Pakistan (Klein and Nestvogel, 1992; Sebayang et al., 2019). The status of women is relatively better in urban and high sections of the society while in rural areas women's rights violations are very serious and terrifying (Karim et al., 2017; Cornish et al., 2021). Around seventy-five percent of the female population of Pakistan lives in rural areas (Shahid, 2004; Sano et al., 2018) and in most rural areas of the country, women live under a feudal system having no values and no access to their rights specified by law and Islam's inclusive teachings (Baig et al., 2017; Cornish et al., 2021). Women are incapable of translating their words into actions due to deep-rooted social and cultural norms.

In Southern Punjab, women live in disadvantageous circumstances and are considered lower-class citizens. Moreover, in these areas, women face greater social as well as cultural discrimination. Poverty, women of low socioeconomic status, traditional norms and regulations of family bounding women from jobs are major constraints regarding women empowerment (Shahid, 2004; Thandar et al., 2019). Women face social, economic and legal discrimination (Agnes, 1996; Karim et al., 2017). There do still exist some cultural and social constraints that hinder women's empowerment and reinforce the negative effect on their health status (Qureshi, 2007; Sohn et al., 2020). The lack of formal education, inappropriate nutrition for girls, lack of social support networks, restriction on mobility outside the home and religious barriers can affect and hinder health-seeking procedures and the health status of women (Noorali et al., 1999; Sano et al., 2018). Another severe traditional status of women regarding Pakistan, women are married at a young age and birth to their first child at an early age. Moreover, in Pakistan, there is inadequate availability of trained health professionals' mainly for females (Ashraf, 1996; Cornish et al., 2021) and less vaccination of tetanus toxoid (TT) available which contributes sky-scraping rate of maternal mortality (Rizvi and Nishtar, 2008; Yaya et al., 2019).

In the scenario of Pakistan, family traditions play a major role regarding the development of the physical, social and mental health status of women. There are many cultural values rooted deeply in traditions that limit women's access to health care facilities and make them dependent on family. According to the World Health Organization (2019), gender inequalities in resource, allocation regarding education and income is significantly associated with poor health and decreased well-being. In Pakistan, there are multiple reasons for poor access and utilization of the healthcare system. Low socioeconomic status of women, limited empowerment, and inadequate availability of physical convenience, cultural norms, and large size of family and the low literacy rate of mothers are some major issues to health care related to women (Katung, 2001; Sano et al., 2018). In traditional constraints, women are not allowed to visit nearby healthcare centers alone to decide so that they can spend money on healthcare (Ahmed, 2000; Chomchoei et al., 2019). Women need to take permission from the household's head or any male in the family to visit the health center. In rural areas, distance from service/ facility and the time needed to achieve the facility has a greater effect to access and utilization of healthcare facilities (Fatmi, 2002; Stephenson, 2004; Karim et al., 2017).

In literature, the scenario of women empowerment is discussed with various aspects some studies focused on economic empowerment and women access (Ahmed, 2000; Fatmi, 2002; Rizvi and Nishtar, 2008; Cornish et al., 2021), women empowerment as a mitigating 
factor (Ashraf, 1996; Stephenson, 2004; Baig et al., 2017; Merrell and Blackstone, 2020), women decision making and choices (Qureshi, 2007; Karim et al., 2017; Peterman et al., 2021), women empowerment and media use (Noorali et al., 1999; Shahid, 2004; Yaya et al., 2019; Sohn and Jung, 2020) and women empowerment and health care decision (Katung, 2001; Sano et al., 2018; Chomchoei et al., 2019; Sebayang et al., 2019; Sohn et al., 2020). In the global scenario, significant literature is available regarding women's health care whereas regarding Pakistan and more specific to Sothern Punjab due to remaining of some feudal social structure no significant literature exists. In addressing this research gap present study focused to investigate the dimensions, determinants, and implications for access to healthcare regarding women empowerment in district Vehari of Southern Punjab Pakistan. This research work is categorized into four segments, first segment illustrated the introduction of the study while data and methodology are indicated in the second segment. Results and discussion were elaborated in the third segment whereas the last segment highlighted the conclusion and suggestions of the study.

\section{Data and Methodology}

\subsection{Selection of study area and data sources}

Punjab province as a study area specifically is selected for some significant reasons. Firstly Punjab most populated (53\%) province of the country (PBS, 2021), secondly, southern Punjab is particularly focused because of the less developed and most deprived area in the province (BOS Punjab, 2019). Thirdly in southern Punjab women significantly contribute to farming by picking cotton, growing and harvesting crops, holding livestock, handmade commodities and fully working in all household activates (BOS Punjab, 2019). Lastly among most deprived districts, district Vehari was randomly selected due to women's lower empowerment because of social and cultural constraints and remaining some feudal practices (BOS Punjab, 2019).

In data collection, a random sampling approach was applied in the study area were in the first stage district Vehari among the most deprived districts of southern Punjab randomly selected. In the second stage, Vehari and Malsi two tehsils were randomly selected in the district while in the third stage one union council from each tehsil was randomly selected. Two villages in each union council were randomly selected in the fourth stage while in the last stage thirty female respondents were randomly selected from each village. An overall sample size of 240 employed and unemployed married female respondents' data was collected from the Vehari district. In data collection, a well-structured and pre-tested questionnaire was developed. Data were collected from a face-to-face meeting with respondents through their formal permission and informing purpose and utilization of data. The reason behind the selection of married female respondents was that they live in the same area for the longest time and can have a better effect on access to healthcare.

\subsection{Selection of empirical model}

The model OLS general form as given below

$$
Y=a_{i}+\sum_{i=1}^{n} \beta_{i} X_{i}+\mu
$$

Ordinary Least Squares regression (OLS) is named linear regression more commonly (simple or multiple which depends on the number of independent variables). Self-esteem, freedom of mobility, role in making a decision and resources control are four major aspects of empowerment of women (Mahmud et al., 2012; Jejeebhoy, 2002). These four components of empowerment of women had used and their scores were obtained by employing the Cronbach's alpha (a) approach that is developed by Lee Cronbach (1951) and also employed by Mahmud et al., (2012).

After estimation of these scores, four models were established to examine the factors that affect the above-explained components of women's empowerment. These models are as follows

$$
\begin{aligned}
& \mathrm{SE}=\lambda_{0}+\lambda_{1} \mathrm{X}_{1}+\lambda_{2} \mathrm{X}_{2}+\lambda_{3} \mathrm{X}_{3}+\lambda_{4} \mathrm{X}_{4}+\lambda_{5} \mathrm{X}_{5}+\lambda_{6} \mathrm{X}_{6}+\lambda_{7} \mathrm{X}_{7}+\lambda_{8} \mathrm{X}_{8}+\lambda_{9} \mathrm{X}_{9}+\lambda_{10} \mathrm{X}_{10}+\epsilon \ldots . \\
& \text { (i) } \\
& \mathrm{RDM}=\sigma_{0}+\sigma_{1} \mathrm{X}_{1}+\sigma_{2} \mathrm{X}_{2}+\sigma_{3} \mathrm{X}_{3}+\sigma_{4} \mathrm{X}_{4}+\sigma_{5} \mathrm{X}_{5}+\sigma_{6} \mathrm{X}_{6}+\sigma_{7} \mathrm{X}_{7}+\sigma_{8} \mathrm{X}_{8}+\sigma_{9} \mathrm{X}_{9}+\sigma_{10} \mathrm{X}_{10}+ \\
& \mu \ldots \ldots \text { (ii) }
\end{aligned}
$$


$M=a_{0}+a_{1} X_{1}+a_{2} X_{2}+a_{3} X_{3}+Y a_{4} X_{4}+a_{5} X_{5}+a_{6} X_{6}+a_{7} X_{7}+a_{8} X_{8}+a_{9} X_{9}+a_{10} X_{10}+$ V.......... (iii)

$\mathrm{COR}=\Pi_{0}+\Pi_{1} \mathrm{X}_{1}+\Pi_{2} \mathrm{X}_{2}+\Pi_{3} \mathrm{X}_{3}+\Pi_{4} \mathrm{X}_{4}+\Pi_{5} \mathrm{X}_{5}+\Pi_{6} \mathrm{X}_{6}+\pi_{7} \mathrm{X}_{7}+\Pi_{8} \mathrm{X}_{8}+\Pi_{9} \mathrm{X}_{9}+\Pi_{10} \mathrm{X}_{10}+$ w........ (iv)

In these models SE, RDM, M and COR show scores as four components regarding women empowerment named as decision-making role of women (RDM), self-esteem (SE), resources control (COR) and mobility $(M)$. In each of the above models, $X_{1}$ is education, $X_{2}$ is type of family, $X_{3}$ is children women have, $X_{4}$ is household head gender, $X_{5}$ refers to women status of the job, $X_{6}$ shows the adequacy of salary, $X_{7}$ is print media access, $X_{8}$ refers to access to television, $X_{9}$ is radio access and $X_{10}$ is access to social media. Finally, a model to observe the effect of dimensions of women empowerment on healthcare access is

$\mathrm{AH}=\mathrm{a}_{0}+\mathrm{a}_{1} \mathrm{SE}+\mathrm{a}_{2} \mathrm{RDM}+\mathrm{a}_{3} \mathrm{M}+\mathrm{a}_{4} \mathrm{COR}+$

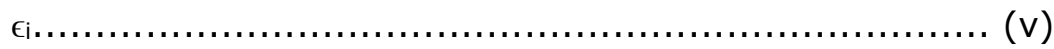

In this model $\mathrm{AH}$ refers to the score of access to healthcare while scores of dimensions of women empowerment are taken as explanatory variables to find out the impact. These scores of access to healthcare were constructed by using the Cronbach's alpha (a) technique. Access to health care was measured through the questions including distance from basic health unit and availability of permission of household's head for women to visit healthcare unit in their villages or outside their village. Values of Cronbach's alpha show the reliability of variables as obtained in the model. It also displays the consistency of the variable on one another. Its value always ranges from 0 to 1 (Bland \& Altman, 1997). Finally, these four components of women empowerment were regressed over the score of health access through Ordinary Least Square (OLS) employed in IBM SPSS Statistics version 23.

\section{Results and Discussion}

Women empowerment and the estimated score of respondents of the study areas have indicated in Table 1. In this table, each component of women's empowerment is further subdivided into some factors to calculate their response. These findings show more women who want to have input in decision-making will have more self-esteem, as indicated dimension of women empowerment as similar to Mahmud et al. (2011) and Baig et al. (2017). Furthermore, most women have power in decision-making while making household decisions and these results are justified by the study of Baig et al. (2017).

Table 1: Responses and components of women empowerment

\begin{tabular}{|c|c|c|c|c|}
\hline \multirow{2}{*}{$\begin{array}{l}\text { She wishes of having an input in the } \\
\text { decision regarding }\end{array}$} & \multicolumn{4}{|c|}{ Self Esteem } \\
\hline & Yes & $\%$ & No & $\%$ \\
\hline Buying the furniture and livestock & 215 & 89.58 & 25 & 10.42 \\
\hline Spending family savings & 213 & 88.75 & 27 & 11.25 \\
\hline Taking a loan & 191 & 79.59 & 49 & 20.41 \\
\hline Visiting a doctor for you & 218 & 90.83 & 22 & 9.1 \\
\hline Her visit outside the home & 217 & 90.41 & 23 & 09.58 \\
\hline \multirow[b]{2}{*}{$\begin{array}{l}\text { She has the power of decision making } \\
\text { in }\end{array}$} & \multicolumn{4}{|c|}{ Decision Making } \\
\hline & $\begin{array}{l}\text { Opinion is } \\
\text { Important }\end{array}$ & $\%$ & $\begin{array}{l}\text { Opinion is Not } \\
\text { Important }\end{array}$ & $\%$ \\
\hline Buying furniture and livestock & 208 & 86.67 & 32 & 13.33 \\
\hline Spending family savings & 215 & 89.59 & 25 & 10.41 \\
\hline Taking a loan & 200 & 83.33 & 40 & 16.67 \\
\hline Visiting a doctor for you & 205 & 85.41 & 35 & 14.59 \\
\hline Her visit outside the home & 199 & 82.92 & 41 & 17.08 \\
\hline \multirow[t]{2}{*}{ Her visit to the home of her father } & 210 & 87.5 & 30 & 12.5 \\
\hline & \multicolumn{4}{|c|}{ Mobility } \\
\hline Last year, she & $\begin{array}{l}\text { Went Without } \\
\text { Permission }\end{array}$ & $\%$ & $\begin{array}{c}\text { Took } \\
\text { Permission } \\
\end{array}$ & $\%$ \\
\hline Visits of friends outside village & 28 & 11.67 & 212 & 88.33 \\
\hline Visited hospital or clinic & 30 & 12.5 & 210 & 87.5 \\
\hline Visited her father home & 42 & 17.5 & 198 & 82.5 \\
\hline Visited her relatives & 51 & 21.25 & 189 & 78.75 \\
\hline Visited her children school & 101 & 42.08 & 139 & 57.92 \\
\hline Going shopping & 51 & 21.25 & 189 & 78.75 \\
\hline Going for outing & 41 & 17.08 & 199 & 82.92 \\
\hline \multirow{2}{*}{$\begin{array}{l}\text { She can spend money according to } \\
\text { her wish }\end{array}$} & \multicolumn{4}{|c|}{ Control over resources } \\
\hline & Yes & $\%$ & No & $\%$ \\
\hline
\end{tabular}




\begin{tabular}{lllcc}
\hline The budget regarding furniture & 111 & 46.25 & 129 & 53.75 \\
Control over husband salary & 134 & 55.83 & 106 & 44.17 \\
Control over own salary & 129 & 53.75 & 111 & 46.25 \\
The budget for other things & 215 & 89.59 & 25 & 10.41 \\
Can sell her precious jewelry & 128 & 53.33 & 112 & 46.67 \\
Can spend the saved money & 207 & 86.25 & 33 & 13.75 \\
Giving the loan to husband's & 173 & 72.09 & 67 & 27.91 \\
family/relatives \\
Giving the loan to her family/relatives & 184 & 76.67 & 56 & 23.33 \\
\hline
\end{tabular}

Source: Response calculation by the author from collected data

The third component of women's empowerment is mobility as shown in table 1 . These findings suggested that most of the women have less mobility and an only little percentage of women showed complete mobility as results are similar to the study of Shah et al. (2011). Results also indicated that more women have control over resources while fewer women have no control over resources. Table 2 showed the description of explanatory variables used in the model with their means and standard deviations where frequencies (\%) are presented in this table.

Table 2: Description of explanatory variables

\begin{tabular}{|c|c|c|c|}
\hline Variable and description & Mean & Std. Deviation & Frequency (\%) \\
\hline Education & 6.24 & 5.804 & - \\
\hline Family type & 0.75 & 0.436 & \\
\hline Joint family $=0$ & & & 25.4 \\
\hline Independent $=1$ & & & 74.6 \\
\hline No. of children & 3.26 & 2.192 & - \\
\hline Household head's gender & 0.06 & 0.243 & \\
\hline $\begin{array}{l}\text { Male }=0 \\
\text { Female = } 1\end{array}$ & & & $\begin{array}{c}93.7 \\
6.3\end{array}$ \\
\hline Job status & 0.22 & 0.416 & \\
\hline Unemployed $=0$ & & & 77.9 \\
\hline Employed/working women $=1$ & & & 22.1 \\
\hline Salary adequacy & 0.29 & 0.455 & \\
\hline Inadequate $=0$ & & & 70.8 \\
\hline Adequate $=1$ & & & 29.2 \\
\hline Access to print media & 0.52 & 0.501 & \\
\hline $\begin{array}{l}\text { If the female household members have no } \\
\text { adequate print media access }=0 \\
\text { If they have an adequate access }=1\end{array}$ & & & $\begin{array}{l}48.3 \\
51.7\end{array}$ \\
\hline Access to Television & 0.91 & 0.283 & \\
\hline $\begin{array}{l}\text { If the female household members have no } \\
\text { adequate TV access }=0 \\
\text { If they have an adequate access }=1\end{array}$ & & & $\begin{array}{l}8.8 \\
91.2\end{array}$ \\
\hline Access to radio & 0.77 & 0.424 & \\
\hline $\begin{array}{l}\text { If the female household members have no } \\
\text { adequate access to radio }=0 \\
\text { If they have an adequate access }=1\end{array}$ & & & $\begin{array}{l}23.3 \\
76.7\end{array}$ \\
\hline $\begin{array}{l}\text { Access to social media } \\
\text { If the female household members have no } \\
\text { adequate access to social media }=0 \\
\text { If they have an adequate access }=1\end{array}$ & 0.60 & 0.490 & $\begin{array}{l}39.6 \\
60.4\end{array}$ \\
\hline
\end{tabular}

The reliability scores of women empowerment components have indicated in table 3 . These scores of women empowerment were calculated by the method of Cronbach's alpha (as used by Jejeebhoy, 2002; Mahmud et al. 2012). The following rule of thumb for value of Cronbach's alpha ( $a$ ) is provided as $a \geq 0.9$ shows excellent consistency, $0.9>a \geq 0.8$ refers good consistency level, $0.8>a \geq 0.7$ shows acceptable consistency, $0.7>a \geq 0.6$ is questionable level of consistency, $0.6>a \geq 0.5$ defines poor consistency and $0.5>a$ is unacceptable consistency level (Tavakol \& Dennick, 2011).

Table 3: Women empowerment scores

\begin{tabular}{llc}
\hline No. & Dimension & Cronbach's alpha Scores (a) \\
\hline $\mathbf{1}$ & Self-esteem & 0.79 \\
$\mathbf{2}$ & Role in decision making & 0.870 \\
$\mathbf{3}$ & Freedom of mobility & 0.892 \\
$\mathbf{4}$ & Control over resources & 0.73 \\
\hline
\end{tabular}

In table 3, self-esteem indicated the aggregate of five different situations has an acceptable internal consistency. The internal reliability (a) of women's general position in 
decision-making score indicates good internal consistency and it was the aggregate of six different conditions. The different factors of mobility have good internal consistency. The final component of women's empowerment is control over resources, which has an acceptable level of internal consistency. After analyzing scores of all four components of empowerment and verifying their internal consistency through Cronbach's alpha (a) method, there were generated four models so that the factors having an impact on women empowerment dimensions can be investigated.

Table 4: The women empowerment regression results of four components

\begin{tabular}{|c|c|c|c|c|}
\hline Factors & $\begin{array}{c}\text { Model } 1 \\
\text { Score of self- } \\
\text { esteem }\end{array}$ & $\begin{array}{c}\text { Model } 2 \\
\begin{array}{c}\text { Score of decision } \\
\text { making }\end{array} \\
\end{array}$ & $\begin{array}{c}\text { Model } 3 \\
\text { Score of mobility }\end{array}$ & $\begin{array}{c}\text { Model } 4 \\
\text { Score of resources } \\
\text { control }\end{array}$ \\
\hline Education & $\begin{array}{c}0.22 * \\
(0.0827)\end{array}$ & $\begin{array}{c}0.069 * * \\
(0.091)\end{array}$ & $\begin{array}{l}0.008^{*} \\
(0.039)\end{array}$ & $\begin{array}{c}0.096^{*} \\
(0.046)\end{array}$ \\
\hline & $0.185^{*}$ & -0.39 & -0.10 & 0.094 \\
\hline Іуре от ramily & $(0.011)$ & $(0.589)$ & $(0.893)$ & $(0.925)$ \\
\hline Children & -0.024 & -0.105 & 0.028 & 0.020 \\
\hline numbers & $(0.722)$ & $(0.121)$ & $(0.681)$ & $(0.776)$ \\
\hline Household & $0.022 *$ & $0.185^{*}$ & 0.80 & $0.120 * *$ \\
\hline head's gender & $(0.748)$ & $(0.008)$ & $(0.259)$ & $(0.090)$ \\
\hline Status of job & 0.021 & 0.11 & 0.049 & $0.013 * *$ \\
\hline 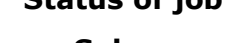 & $(0.809)$ & $(0.897)$ & $(0.568)$ & $(0.081)$ \\
\hline Salary & 0.035 & $0.140 * *$ & $0.147 * *$ & -0.093 \\
\hline adequacy & $(0.670)$ & $(0.089)$ & $(0.079)$ & $(0.267)$ \\
\hline \multicolumn{5}{|c|}{ Media access } \\
\hline Print & $\begin{array}{c}0.020 \\
(0.809)\end{array}$ & $\begin{array}{c}0.047 \\
(0.567)\end{array}$ & $\begin{array}{c}-0.060 \\
(0.479)\end{array}$ & $\begin{array}{l}-0.008 \\
(0.922)\end{array}$ \\
\hline Television & $0.0004 * *$ & $0.93^{*}$ & -0.297 & 0.046 \\
\hline Television & $(0.060)$ & $(0.013)$ & $(0.767)$ & $(0.541)$ \\
\hline Radio & $\begin{array}{l}-0.95 \\
(0.257)\end{array}$ & $\begin{array}{c}0.087 \\
(0.298)\end{array}$ & $\begin{array}{l}-0.265 \\
(0.791)\end{array}$ & 0.011 \\
\hline Social media & $0.151 * *$ & $\begin{array}{c}(0.290) \\
-0.31\end{array}$ & $\begin{array}{c}(0.191) \\
0.378\end{array}$ & $\begin{array}{l}(0.093) \\
-0.001\end{array}$ \\
\hline social media & $(0.089)$ & $(0.726)$ & $(0.706)$ & $(0.994)$ \\
\hline Constant & 0.792 & 0.375 & 0.434 & 0.792 \\
\hline Constant & $(0.2740)$ & $(0.2644)$ & $(0.2498)$ & $(0.2263)$ \\
\hline Adj $\mathbf{R}^{2}$ & 0.07 & 0.13 & 0.24 & 0.22 \\
\hline
\end{tabular}

* Significance level at 5percent, $* *$ significance level at 10 percent

Regression results of these four models as indicated in above table 4 . The first component of women empowerment results indicated women having more education, a smaller number of children, living in the self-governing family system, having the female household head, employed and having adequate salary have supplementary self-esteem as compared to others. Finally, as indicated, women having more adequate print media access, social media and TV are more self-esteemed while contrasting outcomes of radio access. Empowerment in role in making the decision results indicated as women who have education, live in joint family systems, less number of children, female household head, employed, adequate salary has more role in decision making as compared to those having less education, independent family systems, male household head and unemployed. Women having adequate access to print media, TV and radio have more power of decision making while social media indicated contrast pictures and negative relationships.

Mobility dimension results indicate that women who have more education, manage joint family systems, have more children, female household heads, are employed with an adequate salary, having greater social media access were found more mobile in contrast to other women. Interestingly women with adequate access to print media, TV and radio were found to be less mobile than women not having access to all these media. Finally, results also indicated that women who are educated, independently living, have fewer children, female household heads, are employed with sufficient salary and have adequate access to TV and radio have more control of resources rather than other women.

The score of healthcare access was 0.83 as indicated a good internal consistency level. Finally, scores of four components of women empowerment were regressed over scores of access to healthcare and their effect was captured and reported in table 5 . Results indicated if women's self-esteem increases by 1 unit their access and usage to healthcare facilities increase 0.044 percent which is statistically significant at a 10 percent level of significance. If 
women's self-esteem and capability to be strengthened women will go beyond health and can organize the policies social as well as economic, so their positions are reinforced in all spheres of life (Samb, 2017). Women with lower self-esteem feel depressed to seek healthcare and not able to complete their household tasks as similar to the study of Gullette (2006). Long-term mistreatment experience damages the self-esteem and self-confidence of women. A woman who experiences violence from her partner is convinced that this violence is stopped if she obeys the wishes of her partner. This has become a barrier for women in seeking better healthcare facilities (Ganley, 1998). These findings are consistent with the studies of Qureshi, (2007), Karim et al., (2017) and Peterman et al., (2021).

If women's power of decision-making increases by 1 unit their access and usage to healthcare facilities will increase by 0.023 units also has a significant association. The ability of women to make decisions at the family or household level determines their access and usage of skillful healthcare services. Increased empowerment of women can enhance their part in decision-making at the level of the household. As a result indicated good interaction with their husbands, freedom from violence at the domestic level, high status of personal autonomy has greater access to healthcare facilities as well as visit outside the home. These results are similar to the studies of Ashraf, (1996), Stephenson, (2004) Anwar et al. (2013) Baig et al.,(2017) and Merrell and Blackstone, (2020).

Table 5: Regression results of women empowerment scores on access to healthcare score

\begin{tabular}{cccc}
\hline Factors & Coefficients & Standard Error & P-value \\
\hline SE score & $0.044^{* *}$ & 0.023 & 0.0580 \\
DM score & $0.023^{* *}$ & 0.017 & 0.0843 \\
Mobility score & $0.102^{* *}$ & 0.074 & 0.0785 \\
COR score & 0.070 & 0.040 & 0.283 \\
Constant & 0.0792 & 0.337 & 0.6230 \\
Adj R & 0.10 & - & - \\
\hline
\end{tabular}

* Significance level at 5 percent, $* *$ significance level at 10 percent

If the mobility of women increases by 1 unit their access and usage to healthcare facilities will increase by 0.102 units. The mobility of women outside their homes increases greater control over their lives, receiving greater access to healthcare facilities, education and markets. Poor physical access has resulted in an important contributor in reducing healthcare services access and utilization. Mobility enables women to make the decision based on their views and ideas. These findings are alike to the studies of Noorali et al., (1999), Fernando (2002), Shahid, (2004), Yaya et al., (2019) and Sohn and Jung, (2020). If women's control over resources increases by 1 unit their access and usage to healthcare facilities will increase by 0.070 units and it is a statistically insignificant relationship as shown in table 5 . A woman with having control over resources and purchase decisions does not need permission from the head of the household for seeking and access to medical facilities. When women control their own money and their husband poses no right to dictate her spending of earning women's resource control makes it possible for them to access healthcare facilities. These findings are similar to the study of Ahmed, (2000), Fatmi, (2002), Boateng and Falanagen (2008), Rizvi and Nishtar, (2008) and Cornish et al., (2021).

\section{Conclusion and Suggestions}

In Pakistan, the government through adequate provision of education and proper legislation is making considerable efforts for women empowerment. The findings of the study indicate socioeconomic factors influence all four components of women empowerment and in their response; a certain variation is present from one component to another. Education, family type, gender of household head and access to TV as well as social media has shown positive and significant effect on self-esteem. There is a positive and significant association in education, gender of household head, salary adequacy and access to Television and decisionmaking component. Moreover, the mobility dimension has been influenced significantly and positively by education and the sufficiency of salary. Finally, education, household head's gender, and job status have a positive and significant association with control over resources. Women empowerment in access to healthcare was investigated which revealed self-esteem, decision-making, and mobility positively and significantly influenced healthcare access while control over resources has not shown any significant association. Social and economic factors 
have a key role in the reinforcement of women's empowerment and improving women's access to healthcare.

There is a need for policies on both local and national levels for improvements in the aspects of women empowerment for improving access to healthcare. Adequate access to education, job opportunities, print media and electronic media are significant measures of increasing women's empowerment. In the current era of technology, electronic media can play a significant role regarding awareness of women's rights. Girl's educational institutes need to extend at the doorstep in village level. The government should introduce microfinance schemes and some training programs at the household level so that women can start their small businesses. Although this is academic research, these results are expected helpful in understanding phenomenon and issues in women empowerment. The suggested instrument will help in the improvement of women's empowerment and enhance chances of adequate access to healthcare in the study area as well as throughout the country.

\section{References}

Agnes, F. (1996). Economic rights of women in Islamic law. Economic and Political Weekly, 2832-2838.

Ahmed, S. M., Adams, A. M., Chowdhury, M., \& Bhuiya, A. (2000). Gender, socioeconomic development and health-seeking behaviour in Bangladesh. Social science \& medicine, 51(3), 361-371.

Anwar, B., Shoaib, M., \& Javed, S. (2013). Women's autonomy and their role in decision making at household level: a case of rural Sialkot, Pakistan. World Appl Sci J, 23(1), 129-136.

Baig, I. A., Batool, Z., Ali, A., Baig, S. A., Hashim, M., \& Zia-ur-Rehman, M. (2018). Impact of women empowerment on rural development in Southern Punjab, Pakistan. Quality \& Quantity, 52(4), 1861-1872.

Bland, J. M., \& Altman, D. G. (1997). Statistics notes: Cronbach's alpha. Bmj, 314(7080), 572.

Bradshaw, S., \& Linneker, B. (2003). Challenging women's poverty. Perspectives on Gender and Poverty Reduction Strategies from Nicaragua and Honduras.

Chomchoei, C., Apidechkul, T., Wongnuch, P., Tamornpark, R., Upala, P., \& Nongkhai, M. P. N. (2019). Perceived factors influencing the initiation of methamphetamine use among Akha and Lahu youths: a qualitative approach. BMC public health, 19(1), 1-11.

Cornish, H., Walls, H., Ndirangu, R., Ogbureke, N., Bah, O. M., Tom-Kargbo, J. F., ... \& Ranganathan, M. (2021). Women's economic empowerment and health related decision-making in rural Sierra Leone. Culture, health \& sexuality, 23(1), 19-36.

Cronbach, L. J. (1951). Coefficient alpha and the internal structure of tests. psychometrika, 16(3), 297-334.

Fatmi, Z., \& Avan, B. I. (2002). Demographic, socio-economic and environmental determinants of utilisation of antenatal care in a rural setting of Sindh, Pakistan. Journal of Pakistan Medical Association, 52(4), 138.

Fernando, P., \& Porter, G. (2002). Balancing the load: women, gender and transport. Zed Books.

Gullette, D. L., \& Lyons, M. A. (2006). Sensation seeking, self-esteem, and unprotected sex in college students. Journal of the Association of Nurses in AIDS Care, 17(5), 23-31.

Jali, M. R. M., \& Islam, G. M. N. (2017). Empowering rural women in Pakistan: empirical evidence from Southern Punjab. Quality \& Quantity, 51(4), 1777-1787.

Jejeebhoy, S. J. (2000). Women's autonomy in rural India: Its dimensions, determinants, and the influence of context. na.

Kandpal, E., \& Baylis, K. (2011). Standing Together: Peer Networks, Female Empowerment, and Child Welfare. Working Paper.

Karim, R., Lindberg, L., Wamala, S., \& Emmelin, M. (2018). Men's perceptions of Women's participation in development initiatives in rural Bangladesh. American journal of men's health, 12(2), 398-410.

Katung, P. Y. (2001). Socio-economic factors responsible for poor utilisation of the primary health care services in a rural community in Nigeria. Nigerian journal of medicine: journal of the National Association of Resident Doctors of Nigeria, 10(1), 28-29.

Khan, M. T., \& Maan, A. A. (2008). Socio-cultural milieu of women's empowerment in district Faisalabad. Pakistan. Journal of Agricultural Science, 45(3), 78-90. 
Klein, H. G., \& Nestvogel, R. (1992). Women in Pakistan: General Conditions, Approaches and Project Proposals for the Development and Vocational Qualification of Women in the Province of Punjab. Vanguard.

Mahmud, S., Shah, N. M., \& Becker, S. (2012). Measurement of women's empowerment in rural Bangladesh. World development, 40(3), 610-619.

Malhotra, A., \& Schuler, S. R. (2005). Women's empowerment as a variable in international development. Measuring empowerment: Cross-disciplinary perspectives, 1(1), 71-88.

Merrell, L. K., \& Blackstone, S. R. (2020). Women's Empowerment as a Mitigating Factor for Improved Antenatal Care Quality despite Impact of 2014 Ebola Outbreak in Guinea. International Journal of Environmental Research and Public Health, 17(21), 8172.

Murtaza, K. F. (2012). Women empowerment through higher education in GilgitBaltistan. International Journal of Academic Research in Business and Social Sciences, 2(9), 343.

Nieuwenhuijze, M., \& Leahy-Warren, P. (2019). Women's empowerment in pregnancy and childbirth: a concept analysis. Midwifery, 78, 1-7.

Noorali, R., Luby, S., \& Hossein Rahbar, M. (1999). Does use of a government service depend on distance from the health facility?. Health policy and planning, 14(2), 191-197.

Patel, R. (2010). Gender equality and women's empowerment in Pakistan. Oxford University Press.

Peterman, A., Schwab, B., Roy, S., Hidrobo, M., \& Gilligan, D. O. (2021). Measuring women's decisionmaking: Indicator choice and survey design experiments from cash and food transfer evaluations in Ecuador, Uganda and Yemen. World Development, 141, 105387.

Qureshi, R., \& Rarieya, J. F. (2007). Gender and education in Pakistan. Oxford University Press.

Rizvi, N., \& Nishtar, S. (2008). Pakistan's health policy: appropriateness and relevance to women's health needs. Health policy, 88(2-3), 269-281.

Samb, O. M., \& Ridde, V. (2018). The impact of free healthcare on women's capability: a qualitative study in rural Burkina Faso. Social science \& medicine, 197, 9-16.

Sano, Y., Sedziafa, A. P., Vercillo, S., Antabe, R., \& Luginaah, I. (2018). Women's household decision-making autonomy and safer sex negotiation in Nigeria: an analysis of the Nigeria demographic and health survey. AIDS care, 30(2), 240-245.

Sebayang, S. K., Efendi, F., \& Astutik, E. (2019). Women's empowerment and the use of antenatal care services: analysis of demographic health surveys in five Southeast Asian countries. Women \& health, 59(10), 1155-1171.

Sohail, M. (2014). Women empowerment and economic development-an exploratory study in Pakistan. Journal of Business Studies Quarterly, 5(4), 210.

Sohn, M., \& Jung, M. (2020). Effects of empowerment and media use by women of childbearing age on maternal health care utilization in developing countries of Southeast Asia. International Journal of Health Services, 50(1), 32-43.

Stephenson, R., \& Hennink, M. (2004). Barriers to family planning service use among the urban poor in Pakistan. Asia-Pacific Population Journal, 19(2), 5-26.

Tasneem, A. (1996). Maternal mortality: a four year review.

Tavakol, M., \& Dennick, R. (2011). Making sense of Cronbach's alpha. International journal of medical education, 2, 53.

Thandar, M. M., Kiriya, J., Shibanuma, A., Ong, K. I. C., Tin, K. N., Win, H. H., \& Jimba, M. (2019). Women's knowledge on common non-communicable diseases and nutritional need during pregnancy in three townships of Ayeyarwaddy region, Myanmar: a crosssectional study. Tropical medicine and health, 47(1), 1-10.

The Express Tribune, 14 February 2017. Retrieved from https://tribune.com.pk/story/1325981/inhuman-treatment-south-punjab-tops-listdomestic-violence-cases/

United Nations (2017). World Population Prospects: The 2017 Revision, Department of Economics and Social Affairs https://www.un.org/development/desa/publications/world-population-prospects-the2017-revision.html

World Health Organization (2019). World Health Statistics 2019: monitoring health for the SDGs Sustainable Development Goals https://www.who.int/publications/i/item/worldhealth-statistics-2019-monitoring-health-for-the-sdgs-sustainable-development-goals 
Yaya, S., Da, F., Wang, R., Tang, S., \& Ghose, B. (2019). Maternal healthcare insurance ownership and service utilisation in Ghana: analysis of Ghana demographic and health survey. Plos one, 14(4), e0214841.

Zakar, R., Zakar, M. Z., Aqil, N., Chaudhry, A., \& Nasrullah, M. (2017). Determinants of maternal health care services utilization in Pakistan: evidence from Pakistan demographic and health survey, 2012-13. Journal of Obstetrics and Gynaecology, 37(3), 330-337. 